Intended for: Journal of Archaeological Science

\title{
Early Bronze Age copper production systems in the northern Arabah Valley: New insights from archaeomagnetic study of slag deposits in Jordan and Israel
}

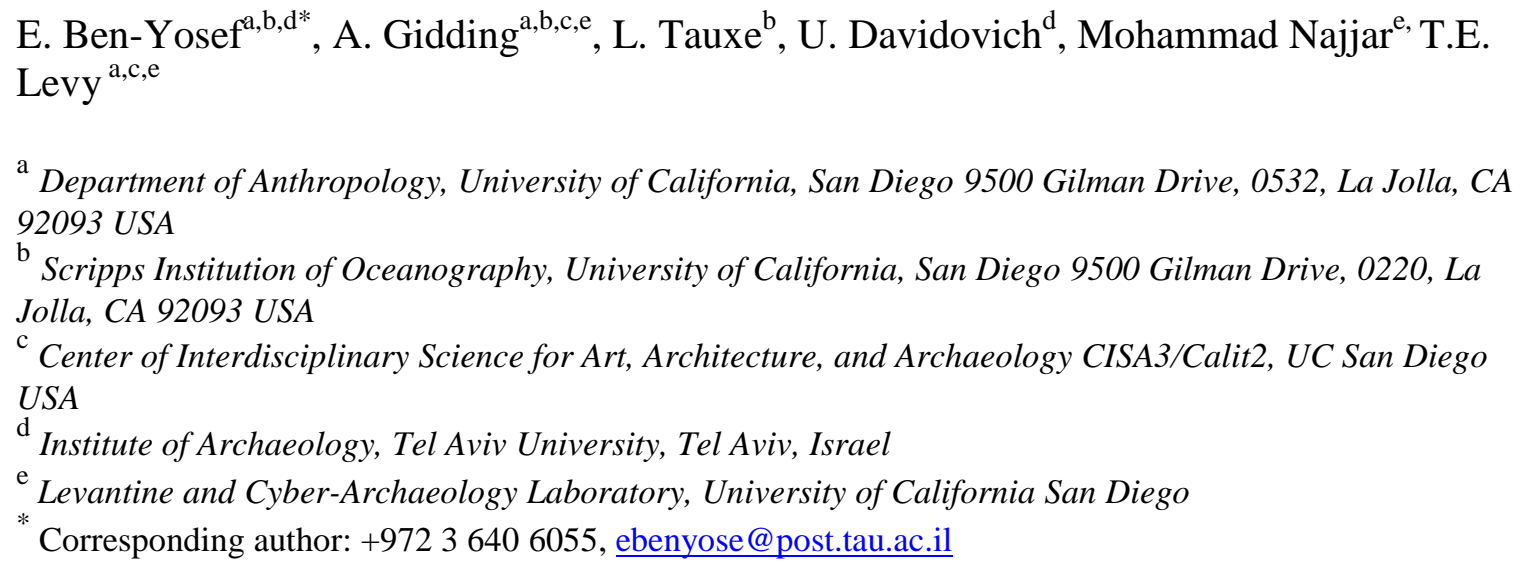




\section{Introduction}

Increasing understanding of changes in the Earth's magnetic field has important implications for dating archaeological sites from the Holocene period. The Earth's magnetic field is constantly changing. Even on short time scales ("secular variations", SV) the changes in its intensity (strength) and directions are substantial, demonstrating an unstable and fluctuating behavior (e.g., Korhonen, et al., 2008). For periods earlier than modern instrumental recording, reconstructing the geomagnetic field's properties depends on geological and archaeological materials that acquired a stable remanent magnetization, usually at the time of their last cooling episode (e.g., Valet, 2003). The record of these fluctuations can, in principle, be used as a dating tool by comparing data from objects of an unknown age to regional reference curves (e.g., Sternberg, 1997).

In recent years, the potential of archaeomagnetic dating has increased dramatically as a result of improvements in resolution and precision of regional reference datasets for the Holocene (e.g., Lanos, 2003 , Pavon-Carrasco, et al., 2011). This includes the dataset for intensity changes in the Levant (e.g., Ben-Yosef, et al., 2008b , Gallet, et al., 2014), which can be used as a reference for dating un-oriented heat-impacted samples. Even taken outside of correlating remanent magnetization to the known historical fluctuations in intensity, identifying differences in magnetic intensities implies different periods of deposition.

In the following we present results of an archaeomagnetic study on slag samples from four copper production sites in the northern Arabah Valley (modern Jordan and Israel) (Fig. 1). The main goal of the study was to use archaeomagnetic data to place these sites in their chrono-cultural context, a fundamental step towards reconstructing copper production and trade systems in the northern Arabah when urbanism first emerged in this part of the Middle East. The sites have attributes that broadly place them in the EB Age; however, as the EB cultures cover more than a millennium and a half, ancient geomagnetic intensity values retrieved directly from slag are used to further constrain the absolute age of the sites. This was done based on comparison to the most updated Levantine Archaeointensity Curve (LAC, Fig. 2; after Shaar, et al., 2016) and to recent data from EB Age Syria (in particular the well-studied site of Ebla [Tell Mardikh], Gallet, et al., 2014). This is a new approach to dating southern Levantine EB Age sites, especially where organic samples suitable for radiocarbon dating are lacking and material culture remains are relatively scant and do not enable clear typo-technological dating. The results are correlated using the newest absolute chronology for the EB Age southern Levant published recently by Regev et al. (2012a , 2012b) based on its division into the EB I, II, III and IV by pottery typology.

\section{Geomagnetic archaeointensity research of slag deposits}

The most commonly used material in archaeomagnetic studies is baked clay (pottery, kilns, and mud bricks) (Thellier, 1938 , Valet, 2003). However, recently Ben-Yosef et al. (2008a) pointed out the advantages of slag material in such studies, and Shaar et al. (2010) demonstrated its high reliability as an archaeointensity recorder. Slag samples can 
have a relatively high success rate in archaeointensity experiments owing to its glassy texture (abundant single domain grains) and high resistance to alteration in the laboratory. Slag samples are rarely found in their original cooling position; therefore, they are ideal only for retrieving intensity values (and not directions). For the Levant (including Israel, Jordan and Cyprus), dozens of slag samples from various periods were analyzed for archaeointensity by Ben-Yosef et al. (2008a) and Shaar et al. (2011 , 2015). The results, complied with data obtained from pottery samples by several other studies, comprise the current Levantine archaeointensity curve (LAC, Fig. 2). The resolution of the LAC was recently improved for the EB Age with data from Ebla, Syria (Gallet, et al., 2014, see above) and for the early Iron Age (1100 - 800 BCE), with data on decadal intervals obtained from stratified slag deposits in Jordan and Israel (Ben-Yosef, et al., 2009, Shaar, et al., 2011). The Iron Age data demonstrate a double peak in intensities ('archaeointensity spikes') reaching values not documented before (Shaar, et al., 2016). These very high values for the period around 1000 BCE have recently been found in nearby Turkey by Ertepinar et al.(2012), and are also documented in the current study.

\section{Smelting sites and sample collection}

Three smelting sites in the northern Arabah Valley ('Ein Yahav, Giv'at Hazeva and Ashalim) and one metallurgical manufactory (Khirbat Hamra Ifdan) in the Faynan copper ore district were investigated as part of the current research (Fig.1). All of these sites should most probably be associated with the ore deposits of Faynan (Hauptmann, 2007), as the next closest major ore source is located more than $100 \mathrm{~km}$ to the south (in Timna, southern Israel).

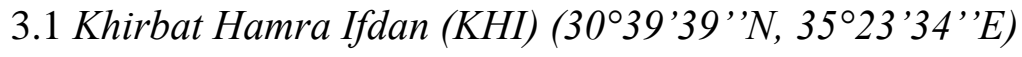

Khirbat Hamra Ifdan is a large (ca. 1.5 ha.) EB metal refining and casting workshop, the largest and best preserved of its kind currently known in the Ancient Near East. Since first discovered in the 1970s, it has been surveyed (Raikes, 1980), sampled (Adams, 1992 , Adams, 1999 , Adams, 2000 , Hauptmann, 2007:134-136) and excavated on a large scale (Levy, et al., 2002). The excavations reported on here were conducted by the expedition of the University of California San Diego and the Department of Antiquities of Jordan over a number of years $(1999,2000,2007,2011$, under the direction of T.E.L. and M.N. - the first two seasons with R. Adams). The 2007 excavations (supervised by A. Muniz) at Areas E and D (Fig. 3) were specifically designed for obtaining slag samples for archaeointensity investigation. KHI represents primarily EB III and EB IV occupation, as indicated by typical ceramic assemblages and radiocarbon dates (see below). Additionally, limited EBII activity has been reported from the lower strata (Levy et al. 2002). The EB III-IV sequence at KHI spans two disparate socio-political organizations in the settled regions of the southern Levant, with a sharp transition from the first urban societies during the EB II-III (e.g., Gophna, 2003, and references therein) to a period of non-urban societies during the EB IV (e.g., Dever, 2003, and references therein). While the EB ceramic typology has been defined early on in the archaeological research of Palestine (Albright, 1949, there EB IV is referred to as Middle Bronze I, and see more on culture history of these periods and their 
terminology in Mazar, 1990), absolute chronology for the sub-phases of the EB Age followed only later, with a major revision published recently (e.g., Regev, et al., 2012a ,

130 Regev, et al., 2012b). For identifying and characterizing synchronic copper production and trade systems in the northern Arabah Valley during the EB Age, we retrieved archaeointensity estimates from slag associated with different contexts at KHI.

The samples used from KHI derive from mixed EB fills below the Iron Age layers, as it was hard to isolate better contexts (e.g., floors). The archaeological accumulation in Area E consists of two distinct types of slag: large fragments of black tap slag densely scattered on the surface, dated to the Iron Age by typological considerations (advanced tapping technology first introduced to the region towards the end of the second millennium BCE; see Hauptmann, 2007), and small grayish pieces sparsely scattered in the fills and occupation levels of the lower strata, associated with EB Age pottery (Fig.4). Samples of the two slag types were collected for archaeointensity inspection. In addition, slag samples were collected from EB Age contexts at Area D (also mostly from fills with loose association to ceramic markers). The exact location and context of slag samples that yielded successful archaeointensity results is shown in the supplementary materials (Supplementary Material \#1, KHI Harris Matrix).

\section{2. 'Ein Yahav $\left(30^{\circ} 36^{\prime} 22^{\prime}{ }^{\prime} N 35^{\circ} 12^{\prime} 05^{\prime} ' E\right)$}

'Ein Yahav is located on a crescent-shaped hill in the western margins of the northern Arabah Valley, $1.5 \mathrm{~km}$ southeast of the small spring of 'Ein Yahav and ca. $14 \mathrm{~km}$ west of the copper mines of Faynan (Fig. 1). Small black pieces of slag mixed with ash and furnace debris are scattered on the hilltop and on the northwestern slopes. The smelting remains are associated with sparse datable ceramic and organic materials, indicating a predominantly EB Age occupation and possibly some Roman activities (Vardi, et al., 2008 , Yekutieli, et al., 2005). Results of a small excavation conducted in 2003 by Yekutieli et al. (2005) included one radiocarbon date (3615 \pm 40 BP; Table 3, Fig. 10) and a diagnostic pot sherd, both indicating activity during the later part of the EB IV.

Yekutieli et al. (2005) also report some copper ore with manganese impurities, typical to the Faynan mines.

We collected surface slag samples from various locations, including the area identified by Yekutieli et al. (2005) as an EB IV smelting workshop. One sample (t) from the latter was subjected to archaeointensity experiments.

\subsection{Giv'at Hazeva (3045'00'’N 35'15'33'’E)}

Similar to the site of 'Ein Yahav and ca. $17 \mathrm{~km}$ to the north, the site of Giv'at Hazeva (Site 260 in B. Rothenberg's unpublished survey, Site 15 in Hazeva Map [\#213] of the Archaeological Survey of Israel, www.antiquities.org.il/survey/new) is located on a hill on the western margins of the northern Arabah Valley (Fig. 1). Also here slag, ash and furnace debris are scattered on the hilltop and on the slopes that face the local western winds. The site has not yet been systematically investigated (Ayalon, 1978); however, the metallurgical remains and their context (wind-blown furnaces on hilltops) suggest EB 
174 Age activity, similar to the excavated site of 'Ein Yahav (Yekutieli, et al., 2005:35) and

175 wind-blown furnaces documented in several sites in Faynan (Hauptmann, 2007, and see

176 below).

178 We collected surface slag samples from the southern face of the hill. Except several

179 Roman to Early Islamic coins of unclear provenance (Israel and Nahlieli, 1983), the site

180 lacks any datable ceramic and seems to represent exclusively copper smelting activities.

\subsection{Ashalim $\left(31^{\circ} 03^{\prime} 35^{\prime \prime} \mathrm{N} 35^{\circ} 20^{\prime} 15^{\prime}{ }^{\prime} \mathrm{E}\right)$}

The site of Ashalim (also Nahal Ashalim) was discovered in 1964 by a survey team of the Masada expedition headed by Y. Tsafrir, and re-surveyed in 2002 by Y. Israel (both unpublished). It is located west of Mt. Sodom, ca. $40 \mathrm{~km}$ northwest of the Faynan copper ore district (Fig.1). Three slag scatters, located at the center of the site, constitute the most distant such deposits from the mines of the Arabah Valley known today. The dominant feature at Ashalim is numerous lines of standing stones, or Masseboth (examples in Fig. 5, features 13, 17), indicating that the site had an important cultic function in addition to its metallurgical one. The Masseboth are reported by U. Avner (2002:65 and Table 11) as part of his monumental study of cultic sites in the deserts of the southern Levant. The site of Ashalim is unique, both in having a large amount of Masseboth at one location (we recorded 99 independent examples) and a wide variety of types ( 5 out of 7 types and 10 out of 18 sub-types in Avner's classification are present at the site). The Masseboth, in general, are considered to represent ancestors or gods, and were worshipped typically by desert societies of the ancient Near East during the $6^{\text {th }}-3^{\text {rd }}$ millennia BCE (Avner, 1984 , Avner, 1993, Avner, 2001). Similar to other sites, also here the Masseboth are systematically facing east, towards the rising sun (Avner, 2002:66).

The three slag scatters, Masseboth and other architectural features at the site were surveyed and mapped by our team during 2008 - 2009, and a few dozens of slag samples were collected (from all scatters) for archaeomagnetic studies (Fig.6a-b, and supplementary material \#2 [KMZ file of mapped features]). The slag spatial relation with the stone features, together with the unique location of the site and lack of stratification, suggests that all finds belong to the same chronological phase. As not a single sherd of pottery or any other datable artifacts were found, the archaeomagnetic study is a key for dating this enigmatic site of copper production and cult.

\section{Experimental procedure}

The experiments for retrieving geomagnetic intensity values from thermally impacted materials are most commonly based on the Thellier-Thellier method (Koenigsberger, 1936, Thellier and Thellier, 1959), in which the natural remanent magnetization (NRM) is gradually replaced by an artificial thermal remanent magnetization (or TRM) in the laboratory using an oven with a controlled magnetic field. In more recent practice of the method, the gradual replacement is done in successive temperature steps and a series of tests are conducted to verify that the mechanism of acquisition of remanent magnetization 
did not alter throughout the experiment and that the requirements of the method are met (e.g., lack of so-called pTRM tails, and present of single component magnetization). For

A total of 71 samples from the sites described above were subjected to archaeointensity experiments. The samples were cut into 332 specimens, each a few $\mathrm{mm}$ in diameter. These were placed in small glass tubes, wrapped in silica filter papers and glued into place with KaSil for processing. The experiments were conducted at the paleomagnetic laboratory at the Scripps Institution of Oceanography. The protocol is based on alternating between heating and cooling the specimens in a known magnetic field (infield step [I]) and in zero field (zero field step [Z]). We included the so-called pTRM-tail check of Riisager et al. (2000) and the pTRM check step (Coe, et al., 1978). In addition, all successful specimens (98) were subjected to either anisotropy of anhysteretic remanence or anisotropy of thermal remanence correction (AC-AARM and AC-ATRM respectively) in order to compensate for possible bias resulting from non-random alignment of the magnetic minerals (Selkin, et al., 2000). Here, we test whether the tensors derived from the anisotropy experiments are significantly anisotropic (based on the F test of Hext (1963), see also Chapter 10 in Tauxe (2010)). Specimens for which isotropy could not be rejected at the $95 \%$ level of confidence were not corrected, but the method (AC-ISO) is noted in the specimen table in the Supplemental Material \#3. Due to the fast cooling rate of slag material, there was no need for cooling rate corrections (see Ben-Yosef, et al., 2008a).

There is no standard procedure for selection of archaeo- or paleo- intensity data (Paterson, et al., 2012) and there are a large number of selection criteria in common use. Here we adopt the same selection criteria used by Ben-Yosef et al. (2009) and detailed in Table 1 . These criteria define the quality of a specimen (i.e., its reliability as an archaeomagnetic recorder) based on its behavior during the experiment. The changes in magnetic remanence on a specimen level during the experiment are commonly presented graphically (Fig. 7), and some of the selection criteria are based on calculations related to these graphs. For example, $\beta$ (Tauxe and Staudigel, 2004) indicates the scatter about the best-fit slopes (green lines in the Arai plots, Fig. 7) and MAD the scatter about the bestfit line from the demagnetization data (end-point diagrams in Fig. 7) (Kirschvink, 1980). For further explanation on the experimental procedure and data processing see in general Tauxe (2010), and in particular for slag material Ben-Yosef et al. (2008a).

\section{Results}

\subsection{Archaeointensity results}

Out of a total of 332 specimens, 107 met the strict selection criteria listed in Table 1. The experimental data and results of all specimens will be uploaded into the MagIC online database (https://earthref.org/MAGIC/); the data for the successful specimens are provided in Supplementary Material \#3. Only sample averages based on at least 2 specimens with standard deviations within $5 \mu \mathrm{T}$ or $15 \%$ are considered here (Table 2). Over half of the results have moderate field intensities of less than $90 \mathrm{ZAm}^{2}$ (the present 
field is approximately $\left.80 \mathrm{ZAm}^{2},\left[\mathrm{Z}=10^{21}\right]\right)$, but $10 \%$ have field values in excess of 150 $\mathrm{ZAm}^{2}$, an unusually high field intensity found in less than $2 \%$ of published dipole moment data in the MagIC database. These high values are characteristic of the

\subsection{Archaeointensity spike recorded in slag deposits at KHI and Giv'at Hazeva}

The overall field intensity during the Iron Age in the Levant was unusually high (140-150

$Z^{2} \mathrm{~m}^{2}$ ). Superimposed on this high field, "spikes" in field intensity in excess of 170 $\mathrm{ZAm}^{2}$ were recently recorded by several studies (Ben-Yosef, et al., 2009, Shaar, et al., 2011, Shaar, et al., 2016). High values at approximately the same age were also found recently in nearby Turkey (Ertepinar, et al., 2012). The current study provides further support for this unique feature in the history of the geomagnetic field. One sample from KHI (b62610a) met our strict selection criteria with VADM in excess of $200 \mathrm{ZAm}^{2}$ (Table 2, Fig. 7). An unprecedented extremely high value was recorded in Giv'at Hazeva (sample p, Table 2), in an undated slag fragment. This value (more than $300 \mathrm{ZAm}^{2}$ ) most probably represents the peak of one of the Iron Age spikes. The new intensity values agree with data published by Ben-Yosef et al. (2009), which included VADM estimates greater than $200 \mathrm{ZAm}^{2}$ (and up to $250.8 \mathrm{ZAm}^{2}$ ).

\subsection{Archaeomagnetic age constraints on smelting sites in the northern Arabah valley}

According to the data available to date for the Levant (LAC, Fig. 2), the high archaeointensity estimates (above $140 \mathrm{ZAm}^{2}$ ) retrieved from Giv'at Hazeva and KHI (Table 2) indicate Iron Age copper smelting activities in both sites. Although the context of the one sample from Giv'at Hazeva (sample p) lacks any supporting contextual evidence for this age, its extremely high intensity value correlates only with the Iron Age spikes (see section 5.2 above). It is not likely that the unprecedented high value from Giv'at Hazeva represents a new, yet unrecorded spike from a different period, as the Iron Age spikes are associated with a unique period of high field intensity (Fig. 2) which is probably a precondition for this phenomenon (Shaar, et al., 2011). Moreover, the sample from Giv'at Hazeva is probably the peak of the earlier and higher spike, dated to around 980 BCE (Fig. 8).

At KHI, the high intensity values were retrieved only from the non-EB tap slag of the upper strata (Fig. 4) that was tentatively dated to the Iron Age by its technology. Evidence at the site that supports an Iron Age date includes a surface find of an Egyptian scarab carrying the name of Pharaoh Shoshenq I (late $10^{\text {th }} \mathrm{c}$. BCE) (Munger and Levy, 2014) and a radiocarbon date of a charcoal obtained from the excavations at Area $L$ (2910 \pm 41 BP; $1192-1021$ BCE $68.2 \%$ and 1261-995 BCE $95.1 \%$ probability; OxCal v.4.2, (C) Ramsey 2013; Stratum IIIA, L. 3034, B.45344, RC23) (Levy, et al., 2012). However, only the archaeointensity data provide direct dating for the slag itself, avoiding problems of context (the charcoal, excavated at the adjacent Area L [Fig. 3], is not directly associated with the slag layer but with a mixed context of EB Age IV pottery, bones and loose sediments) and typology (slag type can at best be used as a terminus post quem (cf. Ben-Yosef, et al., 2010)). Moreover, as the archaeointensity estimates include 
312 the unique values of the spikes $\left(226 \pm 6 \mathrm{ZAm}^{2}\right)$, we suggest that smelting activity here was 313 conducted around 980 BCE, similar to Giv'at Hazeva (Fig. 8).

Our archaeointensity estimates for EB Age slag from KHI form two tight groups (Table 2, Fig. 9) with chronological significance. The higher group, averaging $93 \pm 9 \mathrm{ZAm}^{2}$ VADM, most probably represents copper production activities starting at the end of the EB III and running through the EBIV, while the lower group, averaging $68 \pm 1 \mathrm{ZAm}^{2}$ VADM, most probably represents copper production activities during the transition from the EB II to the EBIII. The magnetic results from the slag of 'Ein Yahav $\left(88 \pm 6 \mathrm{ZAm}^{2}\right.$ VADM) correspond to the higher (i.e., later) group and probably date to the later part of the EBIV, in accordance with the previously obtained radiocarbon date for the site (Section 3 above). Giv'at Hazeva yielded very similar magnetic results to 'Ein Yahav $\left(87 \pm 6.5 \mathrm{ZAm}^{2} \mathrm{VADM}\right)$, probably indicating concurrent activity. The site of Ashalim yielded archaeointensity values that are in an excellent agreement with slag that corresponds to the earlier group at KHI $\left(67 \pm 11 \mathrm{ZAm}^{2}\right.$ VADM). This most probably indicates that metallurgical activity at Ashalim took place around the end of the EB II.

In addition, previously published archaeomagnetic data for slag from EB Age Faynan should be reexamined in light of the new data from Syria (Gallet, et al., 2014) and the new absolute chronology for the EB Age suggested by Regev et al. (2012a , 2012b) (Fig. 9). The site of Faynan 15 (Hauptmann, 2007) yielded archaeomagnetic intensity values of 99.3 \pm 1 and 100 \pm 15 ZAm $^{2}$ (Ben-Yosef, et al., 2008b:Table 2) and should most probably be dated to the late EB III - EB IV (and not EB II-III as previously published). In addition, the site of Timna 149 yielded values of $85.5 \pm 8.59 \mathrm{ZAm}^{2,} \mathrm{VADM}$, matching the same time span (Ben-Yosef, et al., 2008b:Table 2). On the other hand, with intensity values of $68.6 \pm 10.2 \mathrm{ZAm}^{2}$ the previously published sample from KHI (Table 2, sample JS08a, cf. Ben-Yosef, et al. 2008a, 2008b) should now be dated to the end of the EB II (and not to the EB IV).

\section{Early Bronze Age copper production in the northern Arabah in light of the new archaeomagnetic data}

The Faynan region (Fig.1) is the largest copper ore district in the southern Levant. Together with the smaller ore districts of Timna and southern Sinai, located 100/300 km to the south (respectively), it played a role in the history of the region as a provider of copper, displaying intermittent exploitation efforts throughout the millennia (e.g., Hauptmann, 2007, Levy, et al., 2014). Current data do not allow to directly connect the northern Arabah copper production center (Faynan and related sites) to its counterpart in the southern Arabah (Timna and related sites) before the Iron Age (Ben-Yosef, 2010). Particularly, the major sites of Tall al-Magass and Hujayrat al-Ghuzlan (Khalil and Schmidt, 2009), dated to the late $5^{\text {th }}$ - early $4^{\text {th }}$ millennia BCE, did not yield any evidence linking them to the north (Hauptmann, et al., 2009).

In Faynan, the earliest evidence of smelting activity comes from the early EB I site of Wadi Fidan 4 (inset to Fig. 1) (Adams and Genz, 1995 , Genz, 1997 , Genz, 2000 , Genz and Hauptmann, 2002 , Hauptmann, et al., 1996). This represents a major transition from 
long distance ore transport and trade intended for the smelting centers in the northern Negev's Beersheva valley during the Late Chalcolithic period (e.g., Levy and Shalev, 3601989 , Shalev, 1994) to the first local control of copper production within Faynan. The early EB I smelting activities in Faynan correspond with significant refining and casting workshops in the southern coastal plain (e.g., the metallurgy at the site of Afridar (Fig.1), and see overview in Avner, 2002:39-64, Milevski, 2011, Segal, et al., 2004), indicating a period of active copper production and trade.

The earliest substantial evidence for copper production in Faynan during the Early Bronze II (ca. 3100 - 2900 BCE) is at Barqa el-Hetiye (Adams, 2003, Adams, et al., 2010 , Fritz, 1994) (inset to Fig. 1). There, slags of copper smelting were recorded on top of nearby hills, while evidence of refinement and further processing of the metal into ingots was documented in association with architectural remains (Hauptmann, 2007). Similar to Barqa el-Hetiye, KHI has evidence of secondary processing of raw copper in association with architecture. The sites, which are ca. $5 \mathrm{~km}$ apart, were responsible for channeling and processing copper produced by wind-operated furnaces on hilltops in their 'territory'. From the two separate centers, copper was exported in the form of ingots and/or final tools to the settled centers to the north and north-west of Faynan. The location of Barqa el-Hetiye and KHI was probably dictated by the nearby water sources (Ein Fidan and Buweirdeh springs, respectively) that enabled more permanent activities and various aspects of the secondary metallurgical processing in these important centers.

Our study shows that the site of Ashalim was probably active during the late EB II, including substantial smelting of ore (most probably from Faynan) and possibly other metallurgical activities. The site is located far from the mines, on the main road between Faynan and the urban center of Arad west of the Dead Sea (Fig. 1). A segment of this road, where it overcomes the western escarpment of the Dead Sea Rift Valley (the Zohar Ascent), was thoroughly studied by Yekutieli (2006a , 2006b), including associated road facilities and pottery dated to the EB II-III transition (Yekutieli, 2009:226-229). While Yekutieli's assumption that this road connected the Arad region with the main cities of the Ghor east of the Dead Sea (e.g., Bab edh-Dhra, Fig. 1), it is now evident that a southern branch was active, and given the significance of copper this branch may have been the more important one. Ceramic correlations between KHI and Arad (Gidding, forthcoming) further testify to the role played by the Faynan region as a supplier of copper to Arad and beyond, in accordance with recent suggestions (Adams, 2003, Gophna and Milevski, 2003 , Hauptmann, et al., 1992 , Hauptmann, et al., 1999), and contra the previous view of southern Sinai as the only source of copper in this period (Amiran, et al., 1973).

It should be stressed, however, that while the Zohar Ascent is clearly associated with material culture remains originating in the cultural milieu of the settled regions to its north and west (Canaan), the unique site of Ashalim is culturally set within the framework of desert cultures (i.e., the "Timnian"; e.g. Rosen, 2011), with its lack of pottery and abundance of typical Masseboth installations. This suggests that if indeed the sites are contemporaneous, Ashalim and Zohar Ascent represent the contact zone between the desert cultures engaged in the production and transport of copper from the 
404

405

406

407

408

409

410

411

412

413

414

415

416

417

418

419

420

421

422

423

424

425

426

427

428

429

430

431

432

433

434

435

436

437

438

439

440

441

442

443

444

445

446

447

448

Arabah and the settled-region culture of southern Canaan, represented most clearly at the site of Arad (Amiran, 1978, Amiran and Ilan, 1996).

The production at Barqa el-Hetiye, and probably at KHI as well, seems to have stopped after the Early Bronze II. At some point, probably toward the later part of the EB III (ca. 2700), KHI was re-established as the prominent copper-processing site in the region, as indicated by pottery typology, radiocarbon dates (Table 3, Fig. 10) and archaeointensity estimates of the present study (Fig. 9). This role continued uninterruptedly into first half of the EB IV (third quarter of the $3^{\text {rd }}$ millennium BCE). During this period, KHI served as a hub for several smelting sites on nearby hilltops, containing wind-operated furnaces, which yielded radiocarbon dates spanning the late EB III - early EB IV sequence (Fig. 10, Table 3, Hauptmann, 2007).

The late EB III - early EB IV copper production is accompanied by a substantial wave of settlement in the central Negev (Cohen, 1999). The connection of these settlements to the Faynan copper industry has been established by various studies (e.g., Goren, 1996, Haiman, 1996, Segal, et al., 1999). In some of these sites fragments of copper ingots from Faynan were found (Hauptmann, et al., 2015), as well as evidence of secondary metallurgical activities (probably production of tools, Segal, et al., 1999). However, the Negev Highland sites were considered exclusively an EB IV phenomenon based on ceramic correlation to the settled provinces to the north, in contradiction to radiocarbon data obtained from the sites themselves (Fig. 10, Table 3, Cohen, 1999). The dates from the Negev sites broadly range between 2700 to $2200 \mathrm{BCE}$, in excellent agreement with the dates from Faynan (Fig. 10).

Until recently, the beginning of the EB IV was placed around 2200 BCE, leading scholars to link the intense copper production and trade network revealed in Faynan and the Negev Highlands with Egypt during the First Intermediate Period (e.g.. Haiman, 1996 , Yekutieli, et al., 2005). However, the new archaeomagnetic results, coupled with radiocarbon data from Faynan and the Negev sites, strongly suggest linking the copper activity with the rise and fall of the Old Kingdom of Egypt (ca. 2680 - 2180 BCE) (cf. Barta, et al., 2001). The new absolute chronological framework of the EB Age for the settled regions of the southern Levant (Regev, et al., 2012a , Regev, et al., 2012b), which places the beginning of the EB IV around $2500 \mathrm{BCE}$, further supports this suggestion by pushing back the date of common EB IV pottery found in the Negev sites (cf. ShahackGross and Finkelstein, 2015:262). Nonetheless, we argue that this production and trade system started already in late EB III (see above), clearly evident at KHI but has yet to be typologically distinguished in the Negev sites (and see Sebanne, et al., 1993). It is worth emphasizing that no copper smelting sites in Faynan and the northern Arabah have diagnostic pottery. The Faynan-Negev copper production and trade activities should be regarded as a distinct system, peripheral to the social processes of the fertile areas of the southern Levant, which is reflected in the continuity in production during the late EB III - early EB IV, in contrast to the dramatic upheavals in the transition between the periods in the fertile region (e.g., Dever, 1989 , Dever, 2003 , Miroschedji, 2009). 
The radiocarbon date from 'Ein Yahav, together with ceramic evidence from KHI (Gidding, forthcoming) and a few dates from the Negev sites (Table 3, Fig. 10) suggest smelting technologies. The archaeointensity data (Fig. 9) do not allow for distinguishing between production phases within the EB IV. The decrease in demand for copper resulting from the demise of the Old Kingdom (contra Haiman, 1996) is reflected in this limited and less integrated phase of production.

After the EB IV copper production in the Arabah Valley ceased for ca. 700 years. The industry's revival in the Late Bronze Age is also related to Egypt, although in a much smaller scale and probably only in Timna, in the southern Arabah (Yagel, et al., forthcoming).

\section{Conclusions}

Archaeointensity estimates are a useful tool for providing age constraints on heatimpacted archaeological materials. In this study, we retrieved archaeointensity data from ancient copper slag samples that were collected in both surveys and excavations at four EB Age copper production sites in Faynan and the northern Arabah Valley. These data, when compared to the LAC and analyzed according to their archaeological setting, provide the following insights regarding EB Age copper production in the largest ore district of the southern Levant:

- KHI was the hub of copper processing and distribution of copper metal in the center of Faynan copper production system, channeling raw copper from smelting sites in its vicinity for further refining and casting of ingots and tools. The first small scale activity took place during the later part of the EB II, contemporaneous to the copper processing site of Barqa el-Hetiye. However, the main phase of activity was during the late EB III - early EB IV, with probable limited activity also in the late EB IV.

- The main phase of copper production in EB Age Faynan strongly coincides with the rise and fall of the Egyptian Old Kingdom. This connection is best manifested in the settlement wave of the Negev Highlands, which predominantly reflects transport of copper in an east-west direction. This phase is the first large scale copper production in the region.

- Copper metallurgy at the site of Ashalim is probably dated to the late EB II. The site, located on the main road between Faynan and Arad, is probably related to copper trade between Faynan and the fertile region of the southern Levant. This unique site includes, in addition to the metallurgical remains, dozens of standing stones, evidence of cultic activity that might be related to copper smelting and/or trade.

- In addition, our study provides new data from two different sites (KHI and Giv'at Hazeva) that support the unique Iron Age archaeointensity 'spikes' (Ben-Yosef, et al., 2009, Shaar, et al., 2011). The archaeointensity values from Giv'at Hazeva are the highest recorded to date (exceeding $300 \mathrm{ZAm}^{2}$ ), and add to our 
understanding of the geomagnetic field, one of the more enigmatic phenomena of the Earth.

\section{Acknowledgments}

We would like to thank the Israel Antiquities Authority and the Departments of Antiquity of Jordan, ACOR, the ELRAP staff and student volunteers, Jason Steindorf for the magnetic laboratory measurements, and Adolfo Muniz for his work in the field. We also thank Uzi Avner for sharing his knowledge about the Ashalim site. We would also like to thank the Israel Mapping Center for providing corrections for our differential GPS. This research was partially supported by NSF grants \#: EAR 0944137 and EAR1141840, BSF grant \#2012359, and Marie Curie FP7-PEOPLE-2012-CIG grant \#334274.

\section{References}

Adams, R.B., 1992. Romancing the Stones: New Light on Glueck's Survey of Eastern Palestine as a Result of Recent Work by the Wadi Fidan Project., in: Bienkowski, P. (Ed.), Early Edom and Moab: The Beginning of the Iron Age in Southern Jordan, Sheffield Archaeological Monographs, Sheffield, pp. 177 - 186. Adams, R.B., Genz, H., 1995. Excavations at Wadi Fidan 4: A Copper Village Complex in the Copper Ore District of Feinan, Southern Jordan, Palestine Exploration Quarterly $127,8-20$.

Adams, R.B., 1999. The Development of Copper Metallurgy During the Early Bronze Age of the Southern Levant: Evidence from the Faynan Region, Southern Jordan., University of Sheffield, Sheffield.

Adams, R.B., 2000. The Early Bronze Age III-IV transition in southern Jordan: evidence from Khirbet Hamra Ifdan., in: Philip, G., Baird, D. (Eds.), Ceramics and Change in the Early Bronze Age of the Southern Levant., Sheffield Academic Press, Sheffield, pp. 379401.

Adams, R.B., 2003. External influences at Faynan during the Early Bronze Age: a reanalysis of building I at Barqa el-Hetiye, Jordan, Palestine Exploration Quarterly 135, 621.

Adams, R.B., Anderson, J.D., Grattan, J.P., Gibertson, D.D., Rouse, L., Friedman, H.A., Homan, M.M., Toland, H., 2010. Report on the First Season of the Barqa Landscape Survey, South-West Jordan, Annual of the Department of Antiquities of Jordan 54, 95120.

Albright, W.F., 1949. The Archaeology of Palestine, Penguin Books, Harmondsworth, Middlesex.

Amiran, R., Beit-Arieh, Y., Glass, J., 1973. The interrelationship between Arad and sites in southern Sinai in the Early Bronze Age II (preliminary report), Israel Exploration Journal 23, 193-197.

Amiran, R., 1978. Early Arad--the Chalcolithic Settlement and Early Bronze City, The Israel Exploration Society, Jerusalem.

Amiran, R., Ilan, O., 1996. Early Arad II. The Chalcolithic and Early Bronze Ib Settlements and the Early Bronze II City: Architecture and Town Planning SixthEighteenth Seasons of Excavations, 1971-1978, 1980-1984, Israel Exploration Society, Jerusalem. 
Avner, U., 1984. Ancient cult sites in the Negev and Sinai deserts, Tel Aviv 11, 115-131. Avner, U., 1993. Masseboth Sites in the Negev and Sinai and Their Significance, in:

542 Aviram, J. (Ed.), Biblical Archaeology Today. Proceedings of the Second International

543 Congress on Biblical Archaeology, Jerusalem, June 1990, Israel Exploration Society,

544 Jerusalem, pp. 166-181.

545 Avner, U., 2001. Sacred Stones in the Desert, Biblical Archaeology Review 27.

546 Avner, U., 2002. Studies in the Material and Spiritual Culture of the Negev and Sinai

547 Populations, During the 6th-3rd Millennia B.C., Hebrew University of Jerusalem,

548 Jerusalem.

549 Ayalon, E., 1978. Hazeva Region - Survey, Hadashot Arkheologiyot 67-68, 63.

550 Barta, M., Cerny, V., Strouhal, E., 2001. Abusir V: the cemeteries at Abusir South I,

551 Roman Misek, Prague.

552 Ben-Yosef, E., Ron, H., Tauxe, L., Agnon, A., Genevey, A., Levy, T.E., Avner, U.,

553 Najjar, M., 2008a. Application of copper slag in geomagnetic archaeointensity research,

554 Journal of Geophysical Research 113.

555 Ben-Yosef, E., Tauxe, L., Ron, H., Agnon, A., Avner, U., Najjar, M., Levy, T.E., 2008b.

556 A New Approach for Geomagnetic Archaeointensity Research: Insights on Ancient Metallurgy in the Southern Levant, Journal of Archaeological Science 35, 2863-2879. Ben-Yosef, E., Tauxe, L., Levy, T.E., Shaar, R., Ron, H., Najjar, M., 2009. Geomagnetic intensity spike recorded in high resolution slag deposit in southern Jordan, Earth and Planetary Science Letters 287, 529-539.

Ben-Yosef, E., 2010. Technology and Social Process: Oscillations in Iron Age Copper Production and Power in Southern Jordan, Anthropology, University of California, San Diego, San Diego.

Ben-Yosef, E., Tauxe, L., Levy, T.E., 2010. Archaeomagnetic dating of copper smelting site F2 in Timna Valley (Israel) and its implication on modeling ancient technological developments, Archaeometry 52, 1110-1121.

Coe, R.S., Gromml'e, S., Mankinen, E.A., 1978. Geomagnetic paleointensities from radiocarbon-dated lava flows on Hawaii and the question of the Pacific nondipole low, J. Geophys. Res. 83, 1740--1756.

Cohen, R., 1999. Ancient Settlement of the Central Negev: The Chalcolithic period, The Early Bronze Age and The Middle Bronze Age 1 (Israel Antiquities Authority Reports 6), Israel Antiquities Authority, Jerusalem.

Dever, W.G., 1989. The Collapse of the Urban Early Bronze Age in Palestine - Toward a Systemic Analysis, in: de Miroschedji, P. (Ed.), L'urbanisation de la Palestine a l'age du Bronze Ancien, BAR International Series, Oxford, pp. 225 - 246.

Dever, W.G., 2003. Social Structure ini the Early Bronze IV Period in Palestine, in: Levy, T.E. (Ed.), The Archaeology of Society in the Holy Land, 3rd printed ed., Leicester University Press/Continuum, London, pp. 282-296.

Ertepinar, P., Langereis, C.G., Biggin, A.J., Marcella, F., Matney, T., Okse, T., Engin, A., 2012. Archaeomagnetic study of five mounds from Upper Mesopotamia between 2500 and 700 BCE: Furth erevidence for an extremely strong geomagnetic field ca.3000 years ago, Earth and Planetary Science Letters 357-358, 84-98.

Fritz, V., 1994. Vorbericht über die Grabungen in Barqa el-Hetiye im Gebiet von Fenan, Wadi el-Araba (Jordanien) 1990, Zeitschrift des Deutschen Palästina-Vereins 110, 125150 . 
Gallet, Y., D'Andrea, M., Genevey, A., Pinnock, F., Le Goff, M., Matthiae, P., 2014. Archaeomagnetism at Ebla (Tell Mardikh, Syria). New data on geomagnetic field

588 intensity variations in the Near East during the Bronze Age, Journal of Archaeological

589 Science 42, 295-304.

590 Genz, H., 1997. Problems in defining a Chalcolithic for southern Jordan, in: Gebel, H.G.K., Kafafi, Z., Rollefson, G.O. (Eds.), The Prehistory of Jordan II. Perspectives from 1997. Studies in Early Near Eastern Production, Subsistence, and Environment 4, Ex oriente, Berlin, pp. 441-448.

Genz, H., 2000. The organization of Early Bronze Age metalworking in the southern Levant, Paléorient 26, 55-65.

Genz, H., Hauptmann, A., 2002. Chalcolithic and EBA Metallurgy in the Sourthen Levant, in: Yalcin, U. (Ed.), Anatolian Metal II, Deutsches Bergbau-Museum, Bochum, pp. 149-158.

Gidding, A., forthcoming. Archaeological Approaches to Commodity Production and Distribution: An Example from the Early Bronze Age of Jordan, Department of Anthropology, University of California, San Diego, San Diego.

Gophna, R., 2003. Early Bronze Age Canaan: Some Spatial and Demographic Observations, in: Levy, T.E. (Ed.), The Archaeology of Society in the Holy Land, 3rd printed ed., Leicester University Press/Continuum, London, pp. 269-280.

Gophna, R., Milevski, Y., 2003. Feinan and the Mediterraneaan during the Early Bronze Age, Tel Aviv 30, 222-231.

Goren, Y., 1996. The southern Levant in the Early Bronze Age IV: the petrographic perspective., Bulletin of the American Schools of Oriental Research 303, 33-72. Haiman, M., 1996. Early Bronze Age IV settlement pattern of the Negev and Sinai desert: views from small marginal temporary sites., Bulletin of the American Schools of Oriental Research 303, 1-32.

Hauptmann, A., 1989. The earliest periods of copper metallurgy in Feinan, Jordan., in: Hauptmann, A., Pernicka, E., Wager, G.A. (Eds.), Old World Archaeometallurgy, Deutsche Bergbau-Museum, Bochum, pp. 119-135. Hauptmann, A., Begmemann, F., Heitkemper, E., Pernicka, E., Schmitt-Strecker, S., 1992. Early copper produced at Feinan, Wadi Araba, Jordan: the composition of ores and copper., Archeomaterials 6, 1-33.

Hauptmann, A., Bachmann, H.G., Maddin, R., 1996. Chalcolithic Copper Smelting: New Evidence from Excavations at Wadi Fidan 4, in: Demirci, S., "zer, A.M., Summers, G.D. (Eds.), Archaeometry '94, T $\square$ bitak, Ankara, pp. 3-10.

Hauptmann, A., Begemann, F., Schmitt-Strecker, S., 1999. Copper Objects from Arad Their Composition and Provenance, Bulletin of the American Schools of Oriental Research 314, 1-17. Hauptmann, A., 2007. The Archaeometallurgy of Copper - Evidence from Faynan, Jordan, Springer, Berlin.

Hauptmann, A., Khalil, L., Schmitt-Strecker, S., 2009. Evidence for Late Chalcolithic/Early Bronze Age I copper production from Timna ores at Tall Magass, Aqaba, in: Khalil, L., Schmidt, K. (Eds.), Prehistoric Aqaba I, Verlag Marie Leidorf, Rahden/Westf. 

Age copper bar ingots from the southern Levant, Bulletin of the American Schools of

632 Oriental Research 373, 1-24.

633 Hext, G.R., 1963. The estimation of second-order tensors, with related tests and designs, 634 Biometrika 50, 353--357.

635 Israel, Y., Nahlieli, D., 1983. Kefar Shahak, Hadashot Arkheologiyot 83, 69.

636 Khalil, L., Schmidt, K., 2009. Prehistoric Aqaba I, Orient-Archäologie, Verlag Marie

637 Leidorf, Rahden/Westf.

638 Kirschvink, J.L., 1980. The least-squares line and plane and the analysis of

639 paleomagnetic data, Geophys. Jour. Roy. Astron. Soc. 62, 699--718.

640 Koenigsberger, J.G., 1936. A comparison between absolute and variometric magnetic

641 measurements, Terrestrial Magnetism and Atmospheric Electricity 41.

642 Korhonen, K., Donadini, F., Riisager, P., Pesonen, L.J., 2008. GEOMAGIA50: an

643 archeointensity database with PHP and MySQL, Geochem. Geophys. Geosyst. 9,

644 doi:10.1029/2007GC1001.

645 Lanos, P., 2003. Bayesian inference of calibration curve, application to

646 Archaeomagnetism., in: Buck, C.E., Millard, A.R. (Eds.), Tools for Chronology,

647 Crossing Disciplinary Boundaries, Springer-Verlag, London, pp. 43-82.

648 Levy, T., Shalev, S., 1989. Prehistoric Metalworking in the Southern Levant:

649 Archaeometallurgical and Social Perspectives, World Archaeology 20/3, 352-372.

650 Levy, T.E., Adams, R.B., Hauptmann, A., Prange, M., Schmitt-Strecker, S., Najjar, M.,

651 2002. Early Bronze Age Metallurgy: A Newly Discovered Copper Manufactory in

652 Southern Jordan., Antiquity 76, 425 - 437.

653 Levy, T.E., Ben-Yosef, E., Najjar, M., 2012. New Perspectives on Iron Age Copper

654 Production and Society in the Faynan Region, Jordan, in: Kassianidou, V., Papasavvas,

655 G. (Eds.), Eastern Mediterranean Metallurgy and Metalwork in the Second Millennium

656 BC, Oxbow books, Oxford, pp. 197-214.

657 Levy, T.E., Najjar, M., Ben-Yosef, E., 2014. New Insights into the Iron Age Archaeology

658 of Edom, Southern Jordan, Cotsen Institute of Archaeology, UCLA, Los Angeles.

659 Mazar, A., 1990. Archaeology of the Land of the Bible, Doubleday, New York.

660 Milevski, Y., 2011. Early Bronze Age Goods Exchange in the Southern Levant: A

661 Marxist Perpective, Equinox, London.

662 Miroschedji, P.d., 2009. Rise and Collapse in the Southern Levant in the Early Bronze

663 Age, Scienze Dell'Antichita 15, 101-129.

664 Munger, S., Levy, T.E., 2014. The Iron Age Egyptian Amulet Assemblage from the

665 Edom Lowlands Regional Archaeology Project, in: Levy, T.E., Najjar, M., Ben-Yosef, E.

666 (Eds.), New Insights into the Iron Age Archaeology of Edom, Southern Jordan - Surveys,

667 Excavations and Research from the Edom Lowlands Regional Archaeology Project

668 (ELRAP), Cotsen Institute of Archaeology, UCLA, Los Angeles, pp. 741-765.

669 Nagata, T., Arai, Y., Momose, K., 1963. Secular variation of the geomagnetic total force

670 during the last 5000 years, J. Geophys. Res. 68, 5277-5282.

671 Nilsson, A., Holme, R., Korte, M., Suttie, N., Hill, M., 2014. Reconstructing Holocene

672 geomagnetic field variation: new methods, models and implications, Geophysical Journal

673 International 198, 229-248. 
674 Paterson, G.A., Biggin, A.J., Yamamoto, Y., Pan, Y., 2012. Towards the robust selection

675 of Thellier-type paleointensity data: The influence of experimental noise, Geochemistry

676 Geophysics Geosystems 13, 1-26.

677 Pavon-Carrasco, F., Rodrigues-Gonzalez, J., Osete, M.L., Torta, J.M., 2011. A matlab

678 tool for archaeomagnetic dating, Journal of Archaeological Science 38, 408-419.

679 Raikes, T.D., 1980. Notes on some Neolithic and later sites in Wadi Araba and the Dead

680 Sea Valley, Levant 12, 40-60.

681 Regev, J., de Miroschadji, P., Boaretto, E., 2012a. Early Bronze Age chronology:

682 radiocarbon dates and chronological models from Tel Yarmuth (Israel), Radiocarbon 54,

683 505-524.

684 Regev, J., de Miroschedji, P., Greenberg, R., Braun, E., Greenhut, Z., Boaretto, E.,

685 2012b. Chronology of the Early Bronze Age in the southern Levant: new analysis for a

686 high chronology, Radiocarbon 54, 525-566.

687 Riisager, J., Perrin, R., Riisager, P., Ruffet, G., 2000. Paleomagnetism, paleointensity and

688 geochronology of Miocene basalts and baked sediments from Velay Oriental, French

689 Massif Central, J. Geophys. Res 105, 883-896.

690 Rosen, S.A., 2011. Desert chronologies and periodization systems, in: Lovell, J.L.,

691 Rowan, Y.M. (Eds.), Culture, Chronology and the Chalcolithic: Theory and Transition,

692 Oxford University Press, Oxford, pp. 71-83.

693 Sebanne, M., Ilan, O., Avner, U., Ilan, D., 1993. The dating of Early Bronze Age

694 settlements in the Negev and Sinai, Tel Aviv 20, 41-54.

695 Segal, I., Halicz, L., Cohen, R., 1999. A Study of Ingots and Metallurgical Remains from

696 'Ein Ziq and Be'er Resisim, Central Negev, Israel, in: Young, S.M.M., Pollard, M.A.,

697 Budd, P., Ixer, R.A. (Eds.), Metals in Antiquity, Archaeopress, Oxford, pp. 179-186.

698 Segal, I., Halicz, L., Kamenski, A., 2004. The metallurgical remains from Ashqelon,

699 Afridar - areas E, G and H, 'Atiqot 45, 311-330.

700 Selkin, P.A., Gee, J.S., Tauxe, L., Meurer, W.P., Newell, A., 2000. The effect of

701 remanence anisotropy on paleointensity estimates: A case study from the Archean

702 Stillwater complex, Earth Planet. Sci. Lett. 182, 403-416.

703 Shaar, R., Ron, H., Tauxe, L., Kessel, R., Agnon, A., Ben-Yosef, E., Feinberg, J.M.,

704 2010. Testing the accuracy of absolute intensity estimates of ancient geomagnetic field

705 using copper slag material, Earth and Planetary Science Letters 290, 201-213.

706 Shaar, R., Ben-Yosef, E., Ron, H., Tauxe, L., Agnon, A., Kessel, R., 2011. Geomagnetic

707 field intensity: How high can it get? How fast can it change? Constraints from Iron Age

708 copper-slag from the southern Levant, Earth and Planetary Science Letters 301, 297-306.

709 Shaar, R., Tauxe, L., Ben-Yosef, E., Kassianidou, V., Lorentzen, B., Feinberg, J.M.,

710 Levy, T.E., 2015. Decadal-scale variations in geomagnetic field intensity from ancient

711 Cypriot slag mounds, Geochemistry Geophysics Geosystems DOI:

712 10.1002/2014GC005455.

713 Shaar, R., Tauxe, L., Ron, H., Ebert, Y., Zuckerman, S., Finkelstein, I., Agnon, A., 2016.

714 Large geomagnetic field anomalies revealed in Bronze and Iron Age archaeomagentic

715 data from Tel Megiddo and Tel Hazor, Israel, Earth and Planetary Science Letters 442,

716 173-185.

717 Shahack-Gross, R., Finkelstein, I., 2015. Settlement oscillations in the Negev Highlands

718 revisited: the impact of microarchaeological methods, Radiocarbon 57, 253-264. 
Shalev, S., 1994. Change in metal production from the Chalcolithic Period to the Early Bronze Age in Israel and Jordan, Antiquity 68, 630-637.

721 Sternberg, R.S., 1997. Archaeomagnetic dating, in: Taylor, R.E., Aitken, M.J. (Eds.), Chronometric Dating in Archaeology, Plenum, New York.

724 Normal Superchron: New data from submarine basaltic glass of the Troodos Ophiolite,

725 Geochem. Geophys. Geosyst. 5, Q02H06, doi:10.1029/2003GC000635.

726 Tauxe, L., 2010. Essentials of Paleomagnetism, University of California Press, Berkeley.

727 Thellier, E., 1938. Sur l'aimantation des terres cuites et ses applications géophysique,

728 Ann. Inst. Phys. Globe Univ. Paris 16, 157-302.

729 Thellier, E., Thellier, O., 1959. Sur l'intensité du champ magnétique terrestre dans le

730 passé historique et géologique, Ann. Geophys. 15, 285--378.

731 Valet, J.-P., 2003. Time variations in geomagnetic intensity, Rev. Geophys. 41,

732 doi:10.1029/2001RG000104.

733 Vardi, J., Shilstein, S., Shalev, S., Yekutieli, Y., 2008. The Early Bronze Age IV Chipped

734 and Ground Stone Assemblage of 'En Yahav and its Relation to Copper Smelting

735 Activities, Journal of the Israel Prehistoric Society 38, 1-20.

736 Yagel, O., Ben-Yosef, E., Craddock, P., forthcoming. Late Bronze Age Copper

737 Production in Timna: New Evidence from Site 3, Levant.

738 Yekutieli, Y., Shalev, S., Shilstein, S., 2005. 'Ein Yahav - a copper smelting site in the

739 'Arava, Bulletin of the American Schools of Oriental Research Supplement 340, 35-55.

740 Yekutieli, Y., 2006a. Is Somebody Watching You? Ancient Surveillance Systems in the

741 Southern Judean Desert, Journal of Mediterranean Archaeology 19, 65-89.

742 Yekutieli, Y., 2006b. Aspects of an Early Bronze Age II-III Polity in the Dead Sea Region, in: Bienkowski, P., Galor, K. (Eds.), Crossing the Rift: Resources, Settlements $745 \quad 103-124$.

746 Yekutieli, Y., 2009. The Har Hemar Site: A northern outpost on the desert margin?, Tel 


\section{Tables}

751 Table 1: Summary of acceptance criteria used in the archaeointensity experiments

752

753

754

755

756

757

758

\begin{tabular}{|l|l|l|l|l|l|l|l|l|}
\hline DRATS & MD $\%$ & $\mathrm{Z}$ & $\beta$ & $F_{v d s}$ & MAD & DANG & $\sigma[\sigma \%]$ & $\mathrm{N}_{\min }$ \\
\hline 20 & 5 & 2 & 0.1 & 0.7 & 10 & 10 & $5 \mu \mathrm{T}[15 \%]$ & 2 \\
\hline
\end{tabular}

$\sigma[\sigma \%]$ : standard deviation cut-off for sample means [expressed as percentage of mean of specimens per sample]; $\beta$ is the scatter statistic defined by Tauxe and Staudigel (2004); MAD is the maximum angular deviation of the demagnetization data of Kirschvink (1980); $\mathrm{N}_{\text {min }}$ : minimum number of specimens per sample (for further explanations and references see Ben-Yosef, et al., 2008a).

759 
Table 2: Successful ${ }^{*}$ slag samples by archaeological context

\begin{tabular}{|c|c|c|c|c|c|c|c|c|}
\hline $\begin{array}{l}\text { Locus/ } \\
\text { Context (for } \\
\text { KHI, cf. supp. } \\
\text { material \#1) }\end{array}$ & Sample & N_B & $\begin{array}{l}\mathrm{B} \\
\text { (uT) }\end{array}$ & s_b & s_bl\% & $\begin{array}{l}\text { VADM } \\
\left(\mathrm{ZAm}^{2}\right)\end{array}$ & s_vadm & $\begin{array}{l}\text { Context } \\
\text { average } \\
\text { (VADM) }\end{array}$ \\
\hline \multicolumn{9}{|c|}{ KHI: EB Age - low intensity group } \\
\hline L.3068 & b62579a & 2 & 34.63 & 1.23 & 3.6 & 67.12 & 2.38 & \multirow{3}{*}{$68 \pm 1$} \\
\hline \multirow[t]{2}{*}{ L.3031 } & b62341a & 2 & 34.85 & 1.25 & 3.6 & 67.54 & 2.42 & \\
\hline & $\mathrm{JS} 08 \mathrm{a}^{\text {*** }}$ & 5 & 36 & 5.328 & 14.8 & 68.6 & 10.2 & \\
\hline \multicolumn{9}{|c|}{ KHI: EB Age - high intensity group } \\
\hline L.3069 & b62596a & 2 & 41.57 & 5.53 & 13.3 & 80.57 & 10.72 & \multirow{6}{*}{$93 \pm 9$} \\
\hline L.3032 & b62306a & 3 & 45.48 & 9.32 & 20.5 & 88.15 & 18.06 & \\
\hline L.3079 & $\mathrm{b} 62425 \mathrm{a}$ & 3 & 48.44 & 1.18 & 2.4 & 93.88 & 2.28 & \\
\hline L.3104 & $\mathrm{b} 62704 \mathrm{a}$ & 2 & 49 & 2.99 & 6.1 & 94.97 & 5.8 & \\
\hline L.3024 & $\mathrm{b} 62214 \mathrm{a}$ & 2 & 49.42 & 1.8 & 3.6 & 95.78 & 3.49 & \\
\hline L. 3020 & b62100a & 2 & 54.87 & 0.21 & 0.4 & 106.3 & 0.4 & \\
\hline \multicolumn{9}{|c|}{ KHI: Upper stratum (Iron Age, see text) } \\
\hline L.3024 & b62006b & 3 & 68.79 & 7.89 & 11.5 & 133.3 & 15.29 & \multirow{8}{*}{$149.5 \pm 12$} \\
\hline L.3024 & b62206a & 3 & 69.54 & 4.1 & 5.9 & 134.8 & 7.94 & \\
\hline L.3083 & $\mathrm{b} 62630 \mathrm{a}$ & 2 & 72.54 & 10.25 & 14.1 & 140.6 & 19.87 & \\
\hline L.3053 & b62391b & 2 & 78.83 & 7.67 & 9.7 & 152.8 & 14.87 & \\
\hline L.3053 & $\mathrm{b} 62356 \mathrm{a}$ & 4 & 79.58 & 12.87 & 16.2 & 154.2 & 24.94 & \\
\hline L.3017 & b62071c & 4 & 79.95 & 10.78 & 13.5 & 155 & 20.89 & \\
\hline L.3083 & $\mathrm{b} 62655 \mathrm{a}$ & 2 & 83.15 & 8.39 & 10.1 & 161.2 & 16.27 & \\
\hline L.3056 & b62448a & 3 & 84.52 & 3.57 & 4.2 & 163.8 & 6.93 & \\
\hline L.3077 & $\mathrm{b} 62610 \mathrm{a}$ & 2 & 116.5 & 3.19 & 2.7 & 225.8 & 6.18 & $226 \pm 6$ \\
\hline \multicolumn{9}{|l|}{ Ashalim: } \\
\hline surface find & ash01a & 3 & 30.83 & 2.48 & 8.1 & 59.45 & 4.79 & \multirow{2}{*}{$67 \pm 11$} \\
\hline surface find & ash01b & 4 & 38.85 & 2.71 & 7 & 74.91 & 5.22 & \\
\hline \multicolumn{9}{|l|}{ Giv'at Hazeva: } \\
\hline surface find & $\mathrm{h}$ & 4 & 42.67 & 8.18 & 19.2 & 82.61 & 15.84 & \multirow{2}{*}{$87 \pm 6.5$} \\
\hline surface find & $\mathrm{r}$ & 7 & 47.4 & 6.76 & 14.3 & 91.76 & 13.09 & \\
\hline surface find & $\bar{p}$ & 2 & 187.7 & 10.95 & 5.8 & 363.4 & 21.2 & $363 \pm 21$ \\
\hline \multicolumn{9}{|l|}{ 'Ein Yahav: } \\
\hline surface find & $\mathrm{t}$ & 9 & 45.21 & 2.99 & 6.6 & 87.65 & 5.79 & $88 \pm 6$ \\
\hline
\end{tabular}

* Excluded from this table are Samples b62656a (no AARM correction) and b62492a (undefined, mixed context, KHI locus 3062)

${ }^{* *}$ Sample published in Ben-Yosef et al. (2008a)

765 N_B: number of successful specimens; estimates of ancient field intensity are given in micro-Tesla (B) and 
Table 3: Compilation of EB II-IV radiocarbon dates from Faynan, the northern Arabah and the Negev

769 Highlands (cf. Fig. 10)

\begin{tabular}{|c|c|c|c|c|c|c|}
\hline \multirow[b]{2}{*}{ Context } & \multirow[b]{2}{*}{ Sample } & \multirow{2}{*}{$\begin{array}{l}\text { Age BP } \\
\text { (uncalibrated) }\end{array}$} & \multirow[b]{2}{*}{ \pm} & \multicolumn{2}{|c|}{$\begin{array}{l}\text { Calibrated BCE (2- } \\
\text { Sigma) }\end{array}$} & \multirow[b]{2}{*}{ Reference } \\
\hline & & & & From & To & \\
\hline \multirow{27}{*}{ 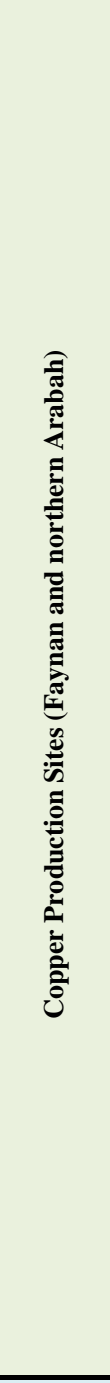 } & \multicolumn{6}{|c|}{ Barqa al-Hetiye } \\
\hline & HD13975 & 4376 & 57 & -3326 & -2891 & (Fritz, 1994) \\
\hline & HD13976 & 4267 & 43 & -3013 & -2701 & (Fritz, 1994) \\
\hline & \multicolumn{6}{|c|}{ Khirbat Hamra Ifdan (KHI) } \\
\hline & HD-16533 & 4044 & 40 & -2848 & -2470 & (Adams, 1999) \\
\hline & Beta-143811 & 4020 & 70 & -2865 & -2342 & (Levy, et al., 2002) \\
\hline & Beta- 143810 & 3970 & 40 & -2579 & -2346 & (Levy, et al., 2002) \\
\hline & Beta-143813 & 3960 & 50 & -2581 & -2295 & (Levy, et al., 2002) \\
\hline & AA68210 & 3949 & 52 & -2579 & -2289 & Unpublished \\
\hline & AA68206 & 3934 & 37 & -2565 & -2297 & Unpublished \\
\hline & AA68207 & 3932 & 42 & -2566 & -2294 & Unpublished \\
\hline & HD-16534 & 3914 & 45 & -2564 & -2214 & (Adams, 1999) \\
\hline & AA68212 & 3850 & 47 & -2467 & -2153 & Unpublished \\
\hline & Beta-143812 & 3650 & 60 & -2201 & -1884 & (Levy, et al., 2002) \\
\hline & \multicolumn{6}{|l|}{ Fenan 9} \\
\hline & HD10577 & 4140 & 109 & -3011 & -2459 & (Hauptmann, 1989) \\
\hline & HD10993 & 3981 & 50 & -2828 & -2309 & (Hauptmann, 1989) \\
\hline & HD10994 & 3973 & 85 & -2858 & -2206 & (Hauptmann, 1989) \\
\hline & HD10584 & 3812 & 77 & -2470 & -2036 & (Hauptmann, 1989) \\
\hline & \multicolumn{6}{|c|}{ Wadi Ghuwair 4} \\
\hline & HD10573 & 4059 & 55 & -2864 & -2470 & (Hauptmann, 2007) \\
\hline & \multicolumn{6}{|l|}{ Ras en-Naqb } \\
\hline & HD10574 & 3971 & 67 & -2837 & -2215 & (Hauptmann, 2007) \\
\hline & \multicolumn{6}{|l|}{ Fenan 16} \\
\hline & HD10579 & 3923 & 61 & -2573 & -2209 & (Hauptmann, 2007) \\
\hline & \multicolumn{6}{|l|}{ Ein Yahav } \\
\hline & RTT-4683 & 3615 & 40 & -2131 & -1884 & $\begin{array}{l}\text { (Yekutieli, et al., } \\
2005 \text { ) }\end{array}$ \\
\hline \multirow{12}{*}{  } & \multicolumn{6}{|l|}{ Ein Ziq } \\
\hline & RT-885A & 3960 & 90 & -2858 & -2201 & (Cohen, 1999) \\
\hline & RT-885B1 & 3880 & 60 & -2559 & -2149 & (Cohen, 1999) \\
\hline & RT-885B & 3850 & 50 & -2468 & -2151 & (Cohen, 1999) \\
\hline & RT-2514 & 3700 & 45 & -2266 & -1951 & (Cohen, 1999) \\
\hline & \multicolumn{6}{|l|}{ Beer Ressisim } \\
\hline & RT-2346 & 4085 & 70 & -2872 & -2484 & (Cohen, 1999) \\
\hline & RT-2347 & 4050 & 50 & -2859 & -2469 & (Cohen, 1999) \\
\hline & RT-2468 & 3930 & 40 & -2565 & -2294 & (Cohen, 1999) \\
\hline & \multicolumn{6}{|l|}{ Har Dimmon } \\
\hline & RT-1557 & 3845 & 50 & -2467 & -2147 & (Cohen, 1999) \\
\hline & RT-1558 & 3565 & 60 & -2124 & -1744 & (Cohen, 1999) \\
\hline
\end{tabular}




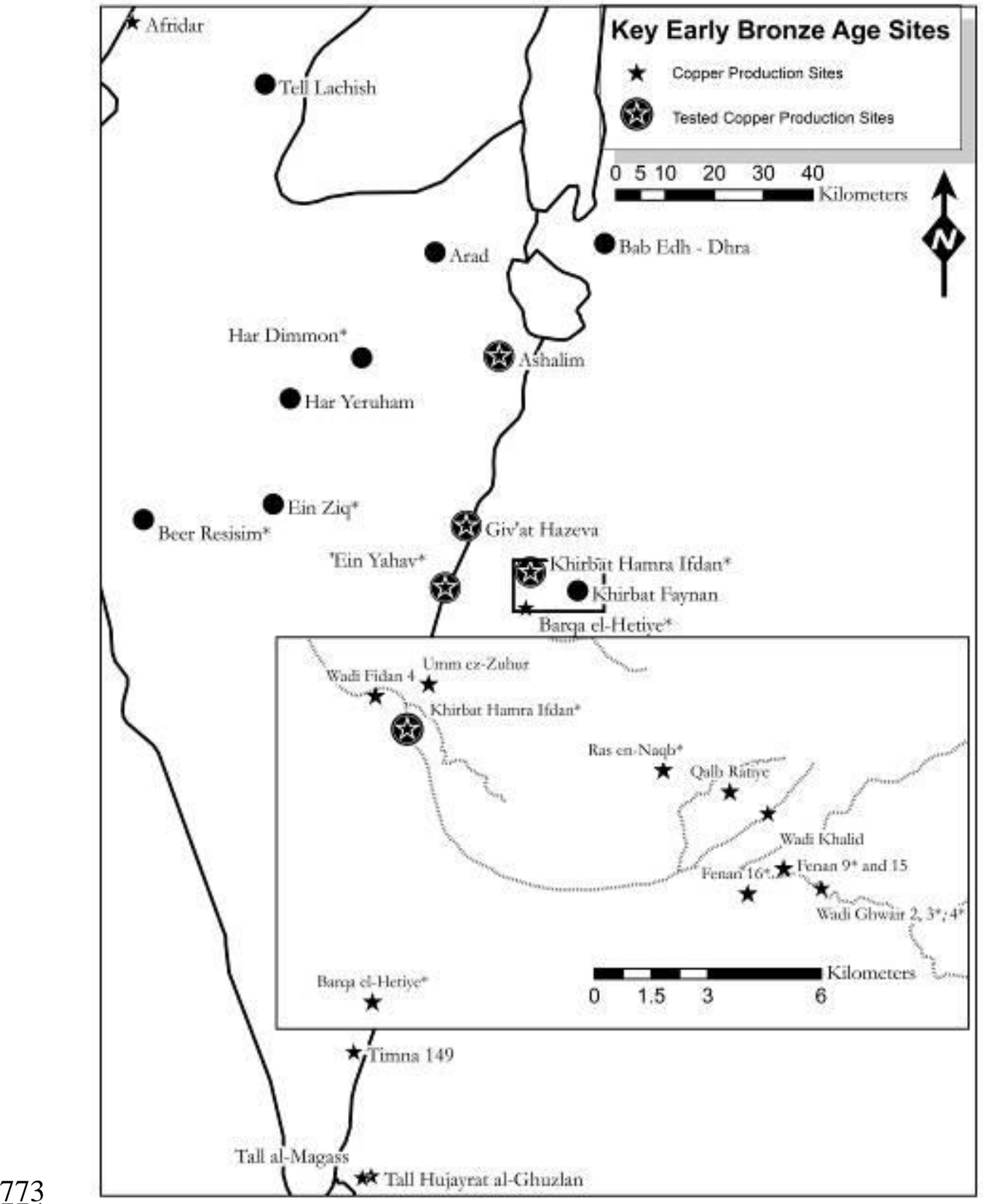

Figure 1: Early Bronze Age sites in the Negev Highlands and the Arabah Valley, with smelting sites tested in the current study emphasized. The inset presents EB Age copper mining, smelting and processing sites within the Faynan copper ore district. Sites with asterisk $\left(^{*}\right)$ are EB II - IV with published radiocarbon 


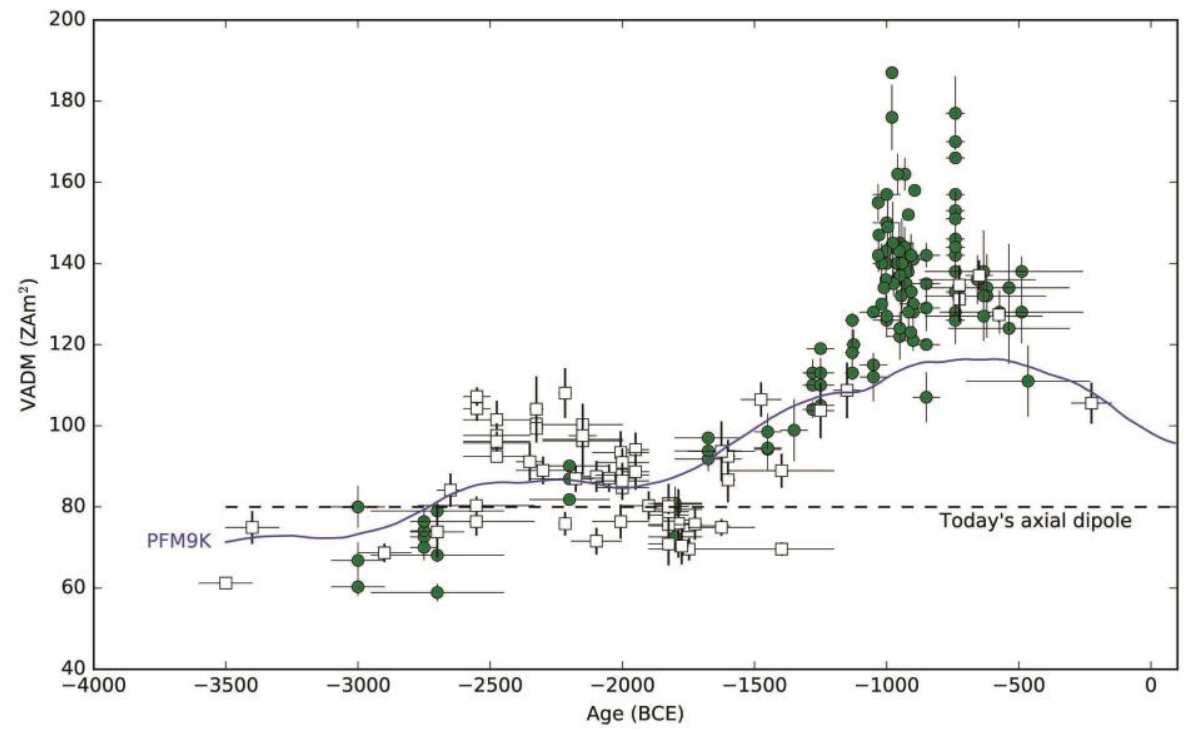

Figure 2: The Levantine archaeomagnetic intensity curve (in Virtual Axial Dipole Moment, VADM;

$\mathrm{Z}=10^{21}$ ), compiled with data from the southern and northern Levant (after Shaar, et al., 2016, and see full

784 references therein). The reference curve (thin blue line) is from the PFM9K model of Nilsson et al. (2014). All data, including results of the current study, are available in the MagIC database (earthref.org). 


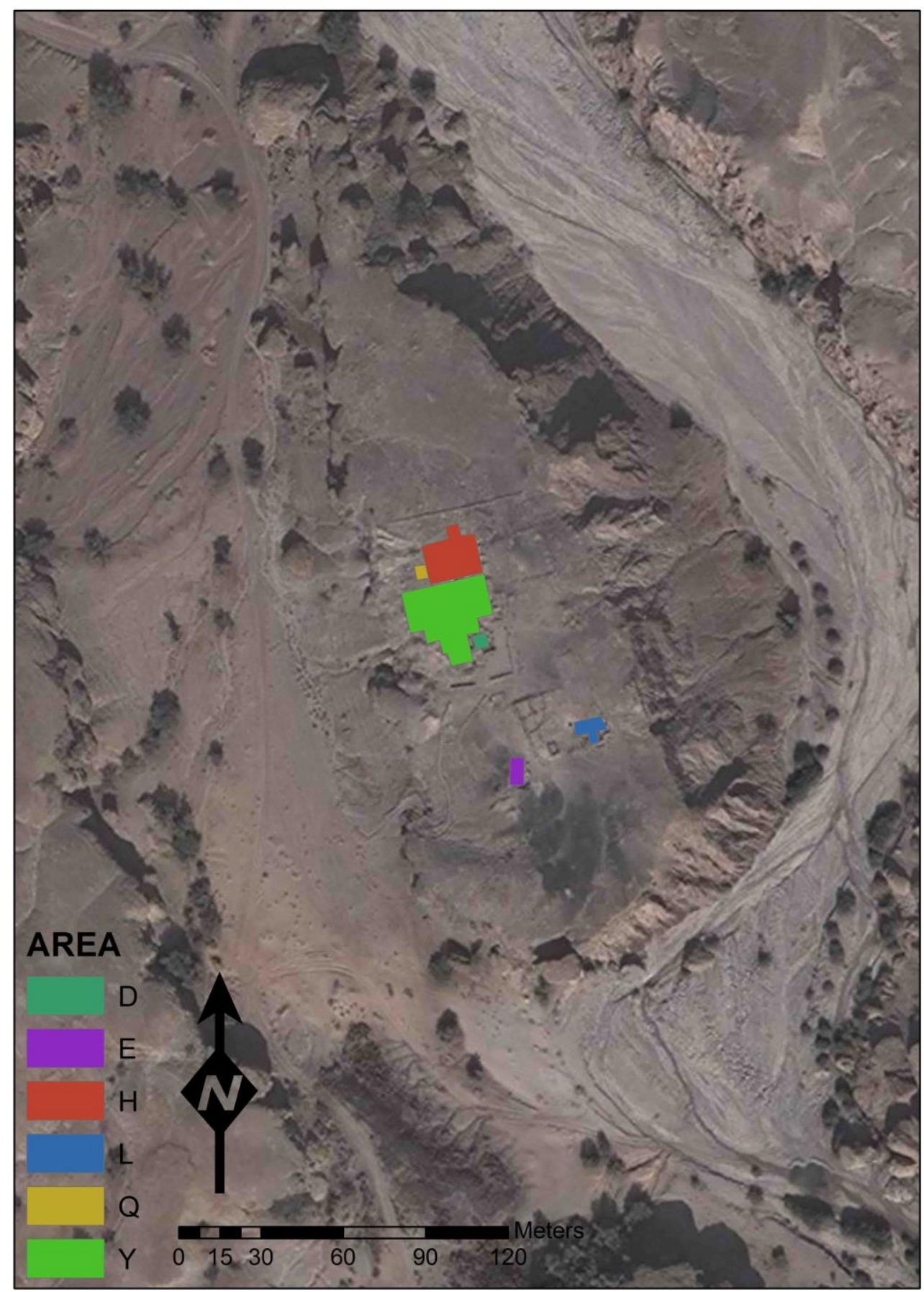

Figure 3: General map (based on Google Earth image) of the excavated areas at Khirbat Hamra Ifdan, an EB Age copper processing center located at the heart of the Faynan Copper Ore District (cf. Fig.1). The site is situated on a small inselberg to the west of Wadi Fidan near the oasis of 'Ein Fidan; the black patch at the southern portion of the site is an Iron Age slag mound (see text for details). 




792 Figure 4: Khirbat Hamra Ifdan (KHI), a section in the excavation of Area E. The distinct stratigraphy is reflected in different types of slag: broken fragments of black solid tap smelting slag at the top layer, and small greyish fragments of melting slag mixed in bright soil at the lower part.


Figure 5: Architectural features at the Ashalim Site. F48: a tumulus on the ridge, looking east; F78: stone 

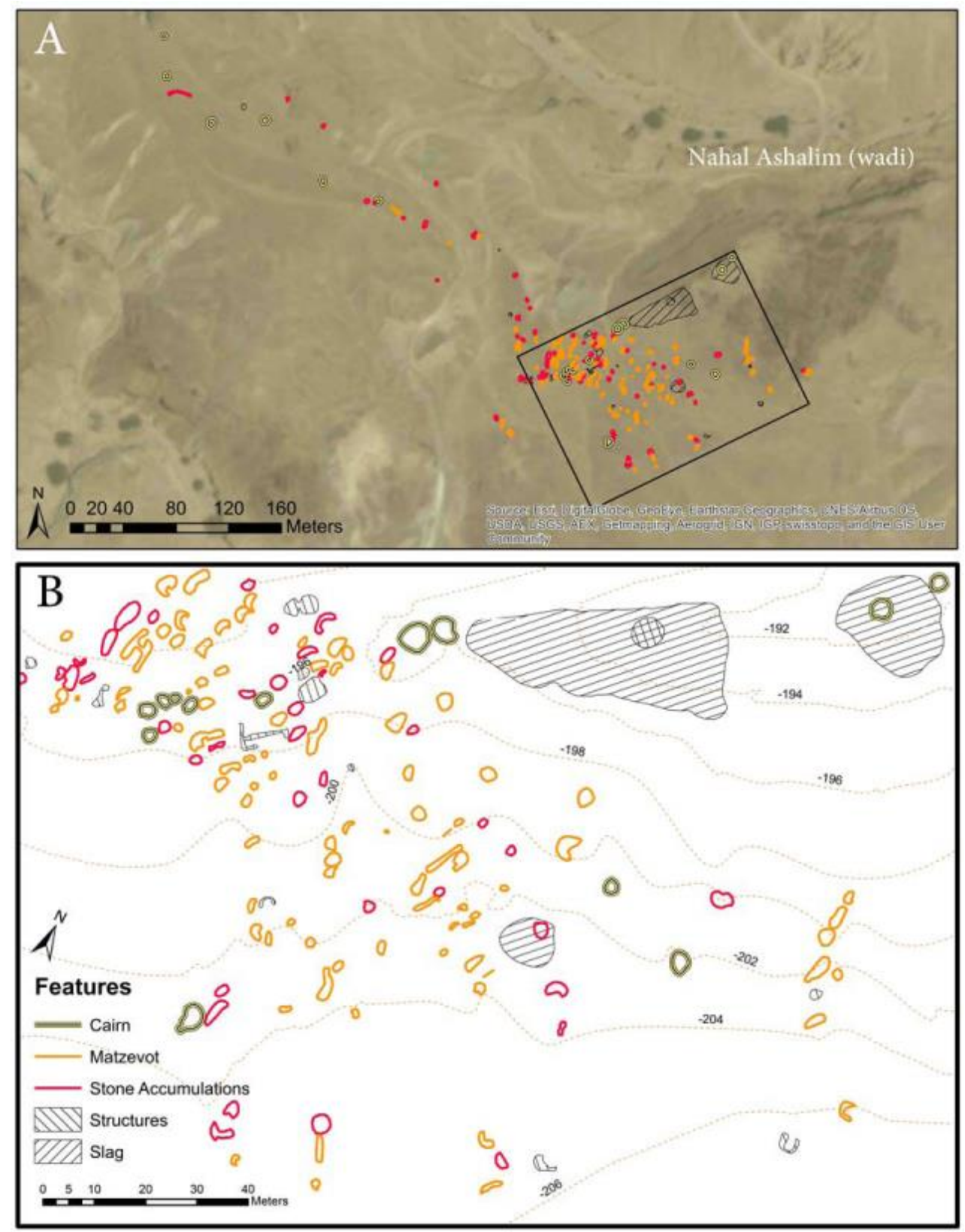

Figure 6: Map of the Ashalim Site on a satellite image (A). The various stone features are located on a low ridge along the southern / southwestern bank of Nahal Ashalim (Wadi Umm Tarafa in Arabic; its dry 804 streambed is indicated by the vegetation on the upper right side of the image). Note the slag scatters, mostly 805 centered at the highest location on the ridge. The center of the site is detailed in figure 6B, where it is 806 noticeable that the standing stones (or Masseboth) are aligned north-south, as they are facing east (in some 807 we recorded offering tables to the east of the stone lines). 

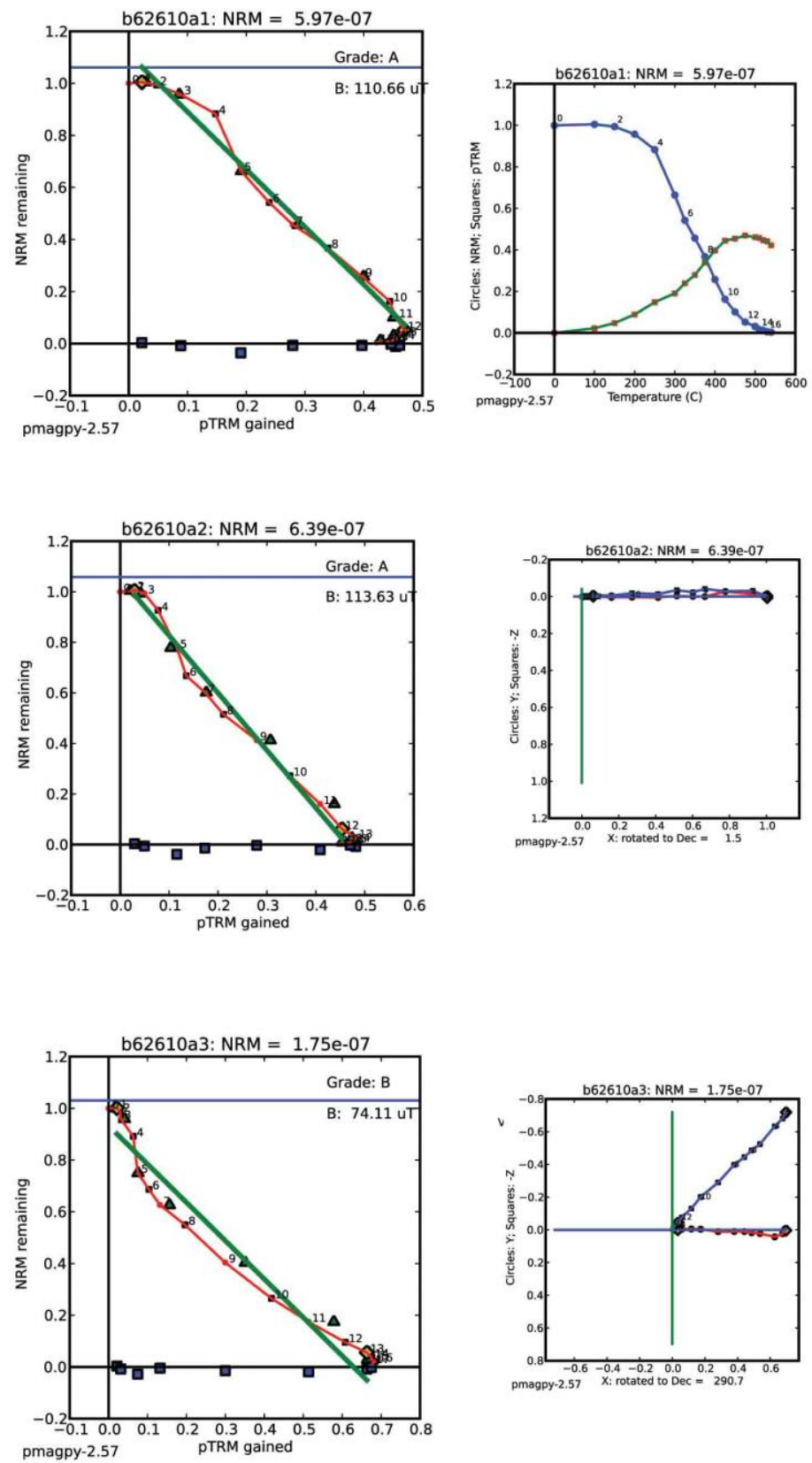

Figure 7: Example of results from archaeointensity experiments on slag sample from KHI. The three pairs of diagrams show results from three specimens obtained from one slag sample. Each point represents a temperature step and the resulting curves the behavior of the specimen throughout the archaeointensity experiment. The two upper specimens demonstrate excellent behavior (Grade A), in contrast to the lower specimen that was rejected because of its low quality (high scatter about the best fitting slope of the left diagram, Grade B). The two specimens indicate an extremely high intensity value for the ancient geomagnetic field (B in the left diagrams; cf. Fig.2 and Table $2-$ there in VADM units $=226 \pm 7 \mathrm{ZAm}^{2}$ ), probably the 'archaeointensity spike' identified by Ben-Yosef et al. (2009) around 980 BCE. The left plots 


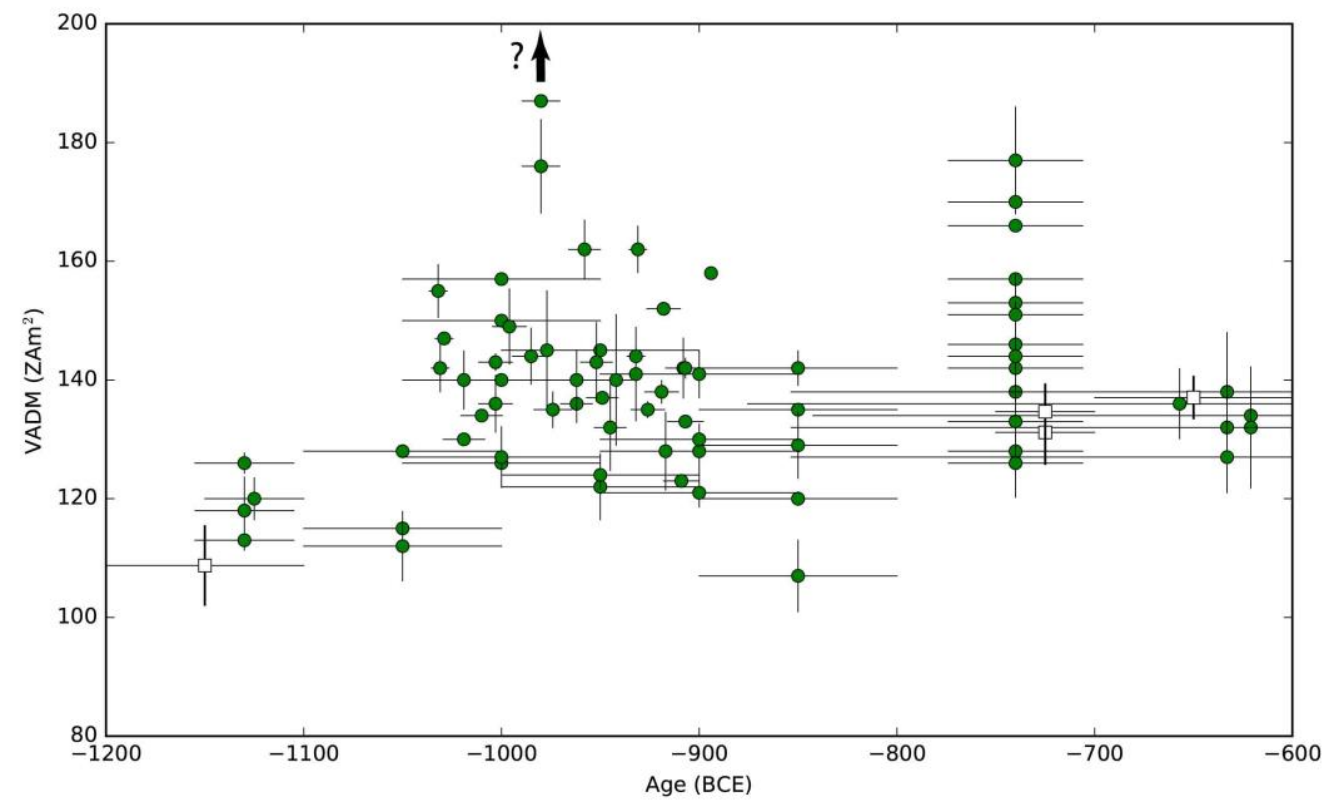

Figure 8: High resolution archaeointensity curve for the early Iron Age Levant indicating two 'spikes' of 823 more than $170 \mathrm{ZAm}^{2}$ (after Shaar, et al., 2016). Data from the current study suggest that the earlier spike 824 (around $980 \mathrm{BCE}$ ) might have reached intensity values of more than $200 \mathrm{ZAm}^{2}$ (cf., Ben-Yosef, et al., 825 2009) (see text). In turn, they also indicate Iron Age smelting at KHI and Giv'at Hazeva. 


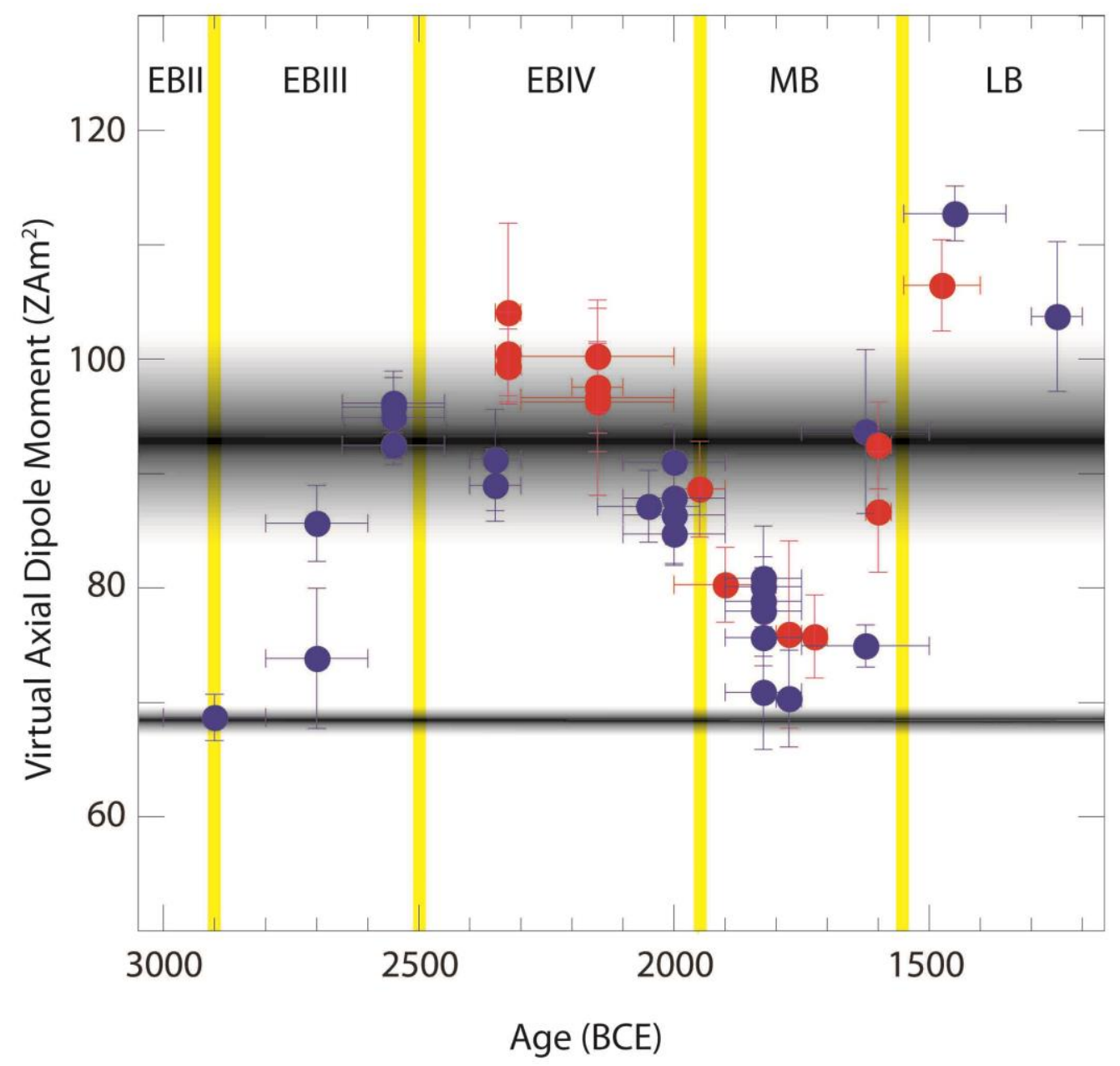

Figure 9: Results of the archaeomangnetic experiments of the current study plotted against geomagnetic

828 values for the EB Age from Syria (Gallet, et al., 2014, in red data from Ebla and in blue from other sites).

829 The EB II-III and EB III-IV boundaries are after the new absolute dating of Regev et al. (2012a, 2012b).

830 The geomagnetic values from the EB Age copper production sites of the southern Levant fall into two tight 831 groups, of high intensities (around $90 \mathrm{VADM} \mathrm{ZAm}^{2}$ ), and low intensity (around $68 \mathrm{VADM} \mathrm{ZAm}^{2}$ ). The 832 shading represents standard deviation of the general mean; cf. Table 2. 


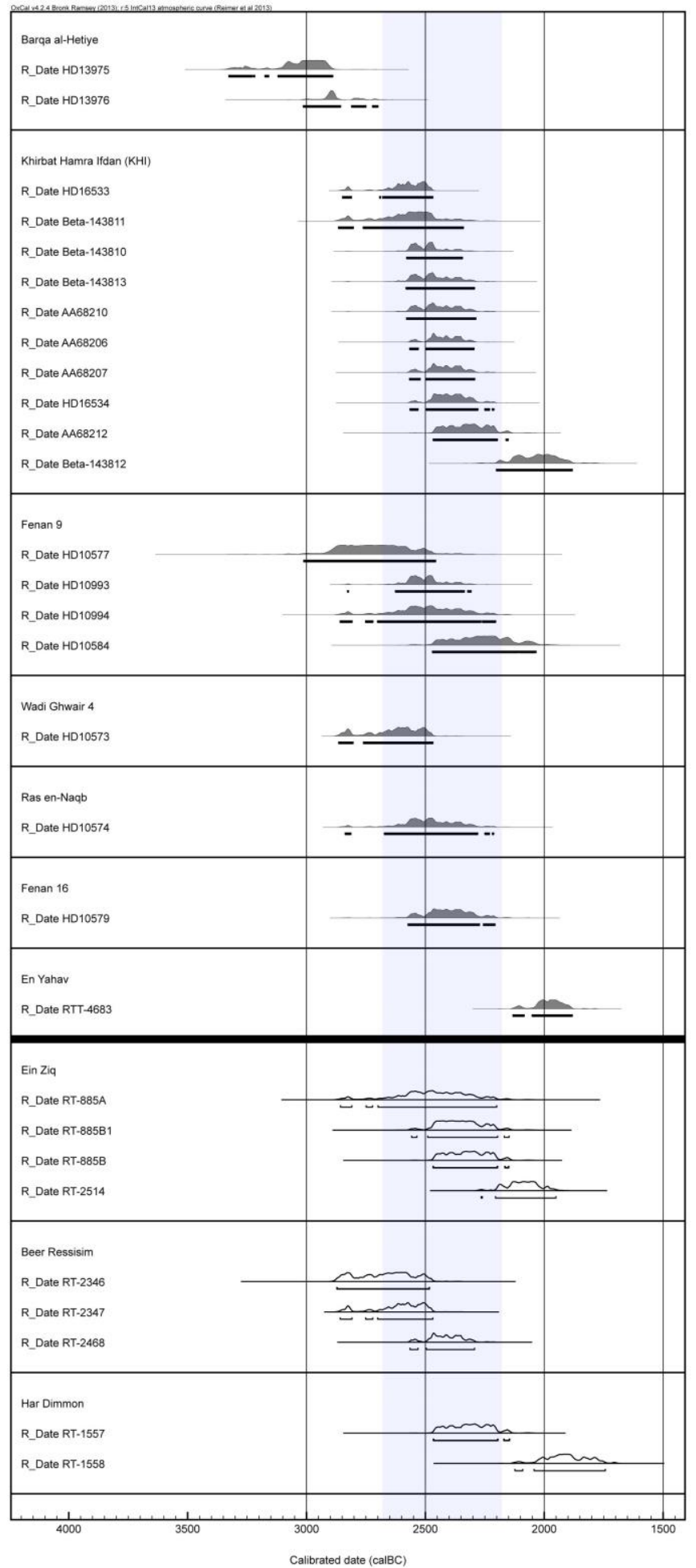

Calibrated date (calBC)

Figure 10: Compilation of calibrated radiocarbon dates (2-sigma) from EB II-IV copper production sites in

Faynan and the northern Arabah (solid gray plots, including new dates from KHI), and the Negev probably does have EB II phase that is not represented by $14 \mathrm{C}$ dates). The plot emphasizes the connection between the Negev sites and the copper industry, and suggests that the main production phase is related to the Old Kingdom of Egypt (indicated by shaded blue). 